\title{
The Civil Service-Collective Bargaining Conflict in the Public Sector: Attempts at Reconciliation
}

The recent growth of public employee unionism poses a serious challenge to the control which civil service commissions ${ }^{1}$ have traditionally exercised over the terms and conditions of public employment.2 Public employee unions are seeking collective bargaining over a broad range of issues ${ }^{3}$-hiring, promotions, transfers, discipline, and dischargewhich are presently governed by civil service. ${ }^{4}$ Union attempts to supplant civil service may be attributable to several considerations, including alleged civil service bias against employees, ${ }^{5}$ union confi-

1 The term "civil service" as used in this comment refers to the broad range of constitutional provisions, statutes, administrative rules, ordinances, and ad hoc administrative determinations relating to the terms and conditions of public employment. It encompasses the activities of personnel boards, agencies, and directors as well as of civil service commissions. The discussion in this comment is applicable to all centralized state or local laws relating to public employment.

Usually a state constitution (see, e.g., Mrch. ConsT. art. XI, §§ 5-6), state statute (see, e.g., Wis. STAT. ANN. $\S \S 63.01-.02$ (Supp. 1970)), or city charter (see, e.g., Grand Rapids, MICH., CharTer tit. VII, § 3) authorizes the establishment of civil service agencies and prescribes certain minimal requirements for these agencies to meet (see, e.g., WIs. STAT. ANN. \& 63.25 (Supp. 1970)). The civil service commission then establishes its own rules within this grant of power, setting standards which it will follow in every case (for example, setting the exact amount of credit to be given seniority in awarding promotions, Cook County, Ill., Rules of the Civil Service Commission, Rule VIII (1968)) or making case-by-case determinations (leaving the weight to be given seniority to be determined as each promotional opportunity arises, Grand Rapids, Mich., Civil Service Rules § 701.3 (1955)).

2 Twenty-three states have civil service systems covering more than $50 \%$ of their employees. Every city of more than 500,000 and $95 \%$ of cities with 100,000 or more population also have some form of civil service. However, fewer than $5 \%$ of the nation's counties have such a system. U.S. CoMm'N on Civil, Rights, For ALL The PEOPLE . . B BY ALL THE PEOPLE 63-64 (1969).

3 For an examination of the issues most often causing conflict between civil service and public employee unions, see Stanley, What Are Unions Doing to Merit Systems? 31 PuB. Pers. Rev. 108 (1970).

4 All compilations of civil service regulations do not cover the same matters. However, subjects generally covered by such regulations are procedures to be followed by the civil service commission, coverage of the regulations, examinations, appointments, probationary periods, demotion, dismissal, discipline, appeals procedures, and political activity. See, e.g., Nevada Personnel Division, Rules for State Personnel Administration (1969); Oregon State Civil Service Rules (1966); INSTITUTE FOR URBAN POLICY AND ADMINISTRation, Graduate School of Public and International Affairs, University of Pittsburgh, Moder Rules and Regulations and forms for Civil Service Commissions in Pennsylvania (1970); League of California Cities, A Suggested Personnel System (1966).

5 The opinion of Thomas Beagley, of Cook County District Council 19, American Federation of State, County, and Municipal Employees, reflects the union rhetoric: 
dence in its ability 'to make better decisions than civil service concerning working conditions, and a possible desire by unions to assume greater importance in the eyes of their members. Whatever the cause, the conflict between collective bargaining and civil service in the public sector presents a choice between two separate decision-making processes - on one hand, unilateral determinations by a civil service commission, and, on the other, collective bargaining between public employers and public employees. ${ }^{\circ}$ At stake is final decision-making power over many aspects of the employment relationship.

To reconcile civil service laws and public sector collective bargaining, and to assign distinct roles to each, is not an easy task. Any resolution of the conflict necessarily involves making assumptions concerning a plethora of issues - the extent of similarity between the public and private sectors, the possibility that public employees may strike to enforce demands on bargainable matters, the desirability of uniformity imposed by civil service regulation in lieu of individually bargained terms of employment, and the potentiality of using civil service to achieve important governmental objectives. ${ }^{7}$

Moreover, the difficulty in reconciling civil service laws and public unionism may reflect their origins in different historical eras as responses to totally different forces. Civil service, which evolved in the late nineteenth and early twentieth centuries, was intended to eliminate the evils of the spoils system-inefficiency, extravagance, and arbitrary dismissals of personnel following each change of political power. ${ }^{8} \mathrm{Com}-$

[I]f a person seeks employment through the Civil Service Commission procedures in the City of Chicago, he finds that the Civil Service Commission . . is appointed by the Mayor who also appoints the department heads, one of which will be his boss. Since 2 of the 3 commissioners may be members of the same political party, the incumbent Mayor is reasonably sure of majority support on the Commission. Politics being what it is, it is difficult to believe that the Commission is not subject to pressure and/or suggestion from the person appointing it.

Beagley, Problems from the Viewpoint of Employees and Unions, in Colnective BargaiNING For Public Eurployees 13, 14 (18th Annual Central Labor Union Conference 1966). See also the account of striking Waukegan, Illinois policemen who refused to appear before a civil service commission hearing because of its alleged management bias. BNA Gov't EMPL. ReL. REP. No. 362, Aug. 17, 1970, at B-15.

6 As two surveys have indicated, the dichotomy between civil service decisions and collective bargaining is not absolute. The Advisory Commission on Intergovernmental Relations found that a civil service commission was the city's representative in collective bargaining in twelve out of 978 cities. ADVISORY COMM'N ON INTERGOVERNMENTAL RELATIONS, Labor Management Policies for State and Local Governments 38 (1969). A survey by the California State Personnel Board found that civil service was a negotiating party in one out of twelve cases. BNA Gov'T EMPL. REL. REP. No. 303, June 30, 1969, at D-5.

7 These issues are discussed in text and notes at notes 68-82 infra.

$8 \mathrm{~K}$. Hanslowe, The Emerging Law of Labor Relations in Public Employment 7 (1969); League of Women Voters of Massachusetrs, The Mert System in MassachuSETTS 3 (1961); Kassalow, Prospective on the Upsurge of Public Employee Unionism, in 
mitted to the creed of individualism, reformers sought to assure every citizen the opportunity to present his qualifications for government employment and to guarantee that the hiring decision would be based solely on merit. Their effort resulted in the establishment of an independent civil service commission, a bipartisan agency appointed by the executive which formulated rules for recruiting, examining, and certifying individuals for appointment by the executive-employer. ${ }^{9}$

The work of the civil service expanded with the passage of time. Personnel practices scientifically developed in private enterprise were adopted to classify and to rate employees for efficient performance. ${ }^{10}$ And since there were no other administrative bodies supervising public employment, civil service authority was gradually extended to include a number of tasks not related to merit hiring, such as training, salary administration, attendance control, morals, safety, and grievances. ${ }^{11}$ With the expansion of responsibilities, the original justifications for civil service-to protect against the evils of the spoils system and to assure equal opportunity to compete for public employment-no longer explained the full range of civil service authority. Thus, civil service administrators justified their agencies as a means to protect advancement opportunities for minority groups, ${ }^{12}$ to determine qualifications for new scientific and technical government positions, ${ }^{13}$ and to attract the most efficient employees to government service. ${ }^{14}$

Public employee unionism, with a few exceptions, developed after the introduction of civil service. ${ }^{15}$ Public employees realized, as did

Collective Negotiation for Public and Professional Employees 20, 25 (R. Woodworth \& R. Peterson ed. 1969).

o Civil service commissions traditionally nominated a group of three candidates who scored highest on civil service examinations, from which the executive could select one. Such a practice deferred to the executive's appointment powers. F. MOSHER, DEMOCRACY ANd THE PUblic Service 69 (1968).

$10 \mathrm{Id}$. at 71 .

11 Advisory Comm'n on InTergovernmental Relations, supra note 6, at 77; NATtonal Governors ConfERENCE, REPORT OF TASK Force on State and LOCAL GOVERNMENT Labor Relations 18 (1967); Kaplan, Civil Service-75 Years, 47 NAT. Mun. Rev. 220, 221 (1958); Rehmus, Constraints on Local Governments in Public Employee Bargaining, 67 MrCH. L. REv. 919, 927 (1969).

12 Hearings on S. 699 and S. 1485 Before the Subcomm. on Intergovernmental Relations of the Senate Comm. on Governmental Operations, 90th Cong., 1st Sess. 203 (1967) (testimony of Charles Meyer) [hereinafter cited as Hearings].

13 See generally Achieving Exceilence in Public Service (S. Sweeny \& J. Charlesworth ed. 1963), indicating that civil service will be instrumental in filling the highly technical and scientific government positions opening up in the future.

14 "[M]any local governments are vitally concerned with the 'quest for quality' and ... the public service is making a real effort to obtain the best person and not only those who have minimum qualifications." Hearings, supra note 12, at 197.

15 W. Heisel \& J. Hallifan, Questions and Answers on Public Employe negotiaTION 8 (1967). 
their counterparts in private enterprise, that they could achieve better wages and working conditions if they organized-a conclusion which instantly placed public unionism in complete opposition to the individualistic bias of civil service. ${ }^{16}$ Some commentators ${ }^{17}$ offer an additional explanation for the growth of public employee unionism. The amount of remuneration they could obtain from legislatures which set pay scales being restricted, employees attached more importance to the less tangible satisfactions found in participation in the formulation and administration of personnel policy. The pursuit of this goal, as well as the tendency of public employees to identify civil service commissions with the state, county, and city employers which they served, brought unionism into direct conflict with civil service.

As might be expected, the responses of state legislatures to this complex, and at times highly controversial, problem have varied greatly. Since collective bargaining by public employees is of questionable legality in the absence of express statutory authorization, the conflict between collective bargaining and civil service is somewhat muted in the nineteen states which have no public collective bargaining laws. ${ }^{18}$ And although public employees in these states occasionally engage in collective bargaining, the power of civil service is virtually absolute.

In those states with both collective bargaining laws and civil service regulations, the response to the conflict has been uneven. One group of fourteen state legislatures has attempted to reconcile the conflict by statute-six of these states give absolute primacy to civil service, ${ }^{19}$ four give primacy to civil service only on certain specifically defined issues, ${ }^{20}$ and four leave the public employer free to determine whether to pursue collective bargaining or to preserve civil service. ${ }^{21}$ In these fourteen states, the statutory resolution provides a degree of certainty. And although the wisdom of the various reconciliations may be open to question, the particular distribution of authority is at least clearly defined.

16 Mosher, supra note 9, at 176. See also Morse, Shall We Bargain Away the Merit System? in Developments in Public Employee Relations 154, 158 (K. Warner ed. 1965).

17 M. Godine, The Labor Problem in the Public Service: A Study of Political Pluralism 11-12 (1951); Rubenstein, The Merit System and Collective Bargaining in Delaware, 20 LAB. L.J. 161, 163 (1969).

18 Arizona, Arkansas, Colorado, Georgia, Illinois, Indiana, Iowa, Kentucky, Mississippi, North Carolina, Ohio, Oklahoma, New Mexico, South Carolina, Tennessee, Texas, Utah, Virginia, and West Virginia.

19 Hawaii, Massachusetts (municipal employees), New Jersey, Pennsylvania, Rhode Island (state employees), and Vermont. The statutes of these states are discussed in text and notes at notes 86.88 infra.

20 Connecticut, Delaware, Louisiana (transit employees), and Maine. The statutes of these states are discussed in text and notes at notes 101-03 infra.

21 California, Nevada, Washington, and Wisconsin (state employees). The statutes of these states are discussed in text and notes at notes 97-100 infra. 
Employers, employees, civil service commissions, and courts are guided by relatively fixed standards. In another group of nineteen states, ${ }^{22}$ however, no statutory attempt has been made to resolve the conflict. As a result, the parties are left in an uncertain and often confused position.

This comment will first proceed to examine judicial attempts to resolve the conflict in those states in which no legislative guidance is provided. It will then discuss several alternative solutions to the problem, including those adopted by various state legislatures.

\section{Judicial Responses to the Conflict in the ABsence of Legislative Direction}

In the nineteen states having both collective bargaining and civil service statutes without legislative reconciliation, the courts themselves must reconcile the two competing decision-making processes. Three states in particular have had extensive judicial consideration of the conflict. The New York courts have established absolute civil service authority over questions concerning the conduct of examinations, ${ }^{23}$ the use of performance ratings, ${ }^{24}$ the arbitration of discharges, ${ }^{25}$ and the classification of positions. ${ }^{20}$ Wisconsin and Michigan, on the other hand, have permitted bargaining on position classification and reclassification, ${ }^{2 \pi}$ department reorganization, ${ }^{28}$ fringe benefits, ${ }^{29}$ and agency shop provisions. ${ }^{30}$

22 Alabama (firefighters), Alaska, Idaho (firefighters), Florida (firefighters), Kansas (teachers), Massachusetts (state employees), Michigan, Minnesota, Missouri, Maryland (teachers), Montana (nurses), Nebraska (teachers), New York, North Dakota (teachers), Oregon, Rhode Island (municipal employees), South Dakota, Wisconsin (municipal employees), and Wyoming (firefighters). A discussion of court attempts to resolve the collective bargaining-civil service conflict follows.

23 Selover v. Civil Serv. Comm'n, 61 Misc. 2d 688 (Sup. Ct. 1970).

24 Kenmore Club v. Civil Serv. Comm'n, 61 Misc. 2d 685 (Sup. Ct. 1970).

25 Board of Educ. v. Associated Teachers of Huntington, Inc., 62 Misc. 2d 906 (Sup. Ct. 1970). See also City of Auburn v. Firefighters Local 1446, N.Y. Pub. Empl. Rel. Bd. Dec. If 1-620 (1968), in which a fact finder advised against a discharge arbitration clause in a collective agreement because no court decision had ever ruled one to be valid.

26 District Council 37, AFSCME v. City of New York, N.Y. Office of Collective Bargaining Dec. No. B-3-69 (1969).

27 Gity of Detroit, Civil Serv. Comm'n v. District Council 77, AFSGME, 71 L.R.R.M. 2026 (Mich. Cir. Ct. 1969); Local 594, Milwaukee Dist. Council 48, AFSCME Petition to Initiate Fact Finding, WERC Dec. No. 9754 (1969); Local 594, Milwaukee Dist. Council 48, AFSCME Petition to Initiate Fact Finding, WERC Dec. No. 8137-B (1967).

28 Local 594, Milwaukee Dist. Council 48, AFSCME Petition to Initiate Fact Finding, WERC Dec. No. 9904 (1970), BNA Gov't EMpL. Rel. REP. No. 368, Sept. 28, 1970, at B-1, enforced, WERC Dec. No. 9904-B, BNA Gov't EMPL. REL. Rep. No. 387, Feb. 8, 1971, at B-9.

29 Rayburn v. Board of Educ., 71 L.R.R.M. 2177 (Mich. Cir. Ct. 1969).

30 Nagy v. City of Detroit, 7I L.R.R.M. 2362 (Mich. Cir. Ct. 1969); Clampitt v. Bd of Educ., 68 L.R.R.M. 2996 (Mich. Cir. Ct. 1968). 
The New York judiciary, in resolving the conflict in favor of civil service, has relied on the absence of any specific indication in the Taylor Law (New York's public employee bargaining statute) that collective bargaining was intended to supplant civil service procedures and powers. As a result, the courts have denied union requests for injunctions against civil service examinations which were to be conducted contrary to the procedures specified in collective bargaining agreements, ${ }^{31}$ holding that a bargaining agreement between a municipality and its employees "although basically sanctioned by the Taylor Act has ... [no] precedence and makes no claim to any precedence over the Civil Service Law."32 In another case, a court voided a contract provision calling for arbitration of discharge disputes because the General Municipal Law specifically excluded discipline and discharge disputes from arbitration. ${ }^{33}$ While noting that the Taylor Law authorizes negotiation of grievances, the court relied upon the failure of the statute to define "grievance" in ruling that the General Municipal Law voided the contract arbitration clause. ${ }^{34}$

Similarly, in an administrative agency decision, ${ }^{35}$ the New York City Office of Collective Bargaining denied a union claim that the city must negotiate on the issue of the creation of additional positions for elevator starters, citing bargaining unit considerations and the management rights provision in the contract between the city and the union. Although the Taylor Law authorized collective bargaining over salaries, wages, hours, and other terms and conditions of employment, the Office ruled that to require mandatory bargaining would violate the right of the city to determine the method, means, and personnel by which its operations were to be conducted. In addition, the Office noted that bargaining over the creation of new positions would interfere with the jurisdiction of another union which represented the elevator starters.

New York, then, has construed the Taylor Law narrowly by requiring explicit statutory language authorizing bargaining on provisions con-

31 In Selover v. Civil Serv. Comm'n, 61 Misc. 2d 688, 689 (Sup. Ct. 1970), a bargaining agreement specified that "examinations for all ranks above fire driver-fire fighter shall be open to all employees who have at least five (5) years of continuous service . . . " The civil service commission was allowed to open an examination for the position of fire chief only to assistant fire chiefs and fre captains. In Kenmore Club v. Civil Serv. Comm'n, 61 Misc. 2d 685, 687 (Sup. Ct. 1970), the agreement stipulated that "personal ratings shall not be used to affect competitive rating ...." The court refused to enjoin an examination which contained a personal performance rating of $20 \%$.

32 Selover v. Civil Serv. Comm'n, 61 Misc. 2d 688, 690 (Sup. Ct. 1970).

33 Board of Educ. v. Associated Teachers of Huntington, Inc., 62 Misc. 2d 906 (Sup. Ct. 1970).

34 Id. at 918.

35 District Council 37, AFSCME v. City of New York, N.Y. Office of Collective Bargaining Dec. No. B-3-69 (1969), 3 CCH LAB. L. REP. I 49,995.15 (1969). 
trary to the civil service laws. In adopting this approach, the courts have refused to consider the merits of the questioned agreements and have failed to explain why they were rejected. Any policy considerations the courts may have relied upon, such as the cost involved in arbitration or doubts about the desirability of arbitration arising from its performance in the private sector, went unstated. Neither public policy nor legislative history was cited.

In striking contrast to the New York decisions is the variety of rationales developed in Wisconsin and Michigan to allow employees to negotiate on some matters covered by civil service regulations. These rationales are of two types-those relating to any conflict of statutes and those relating specifically to the unique problems of the civil servicecollective bargaining conflict.

In the former category, the general doctrine establishing the superiority of state statutes to local ordinances has been relied upon by at least one Michigan court $^{36}$ in resolving the conflict between civil service and collective bargaining. In that case, the court rejected the claim of the Detroit Civil Service Commission that it had exclusive jurisdiction over classification and position allocation. To reach this result, the court cited Michigan constitutional provisions subordinating city ordinances to state statutes and concluded that the state public employee bargaining statute prevailed over the local civil service regulations. ${ }^{37}$ This approach, however, has only limited potential for resolving the conflict between civil service and collective bargaining. Later decisions noted, ${ }^{38}$ for example, that the establishment of local civil service commissions is authorized by the Michigan state constitution, and that a civil service system cannot be modified or discontinued without approval by the majority of voters within a chartered locality. ${ }^{39}$ Since civil service regulations are products of constitutional authorization and popularly enacted city charters, they cannot be supplanted by collective bargaining agreements which derive their legitimacy only from statutes. ${ }^{40}$

The general supremacy argument is even less convincing where the

36 City of Detroit Civil Serv. Comm'n v. District Council 77, AFSCME, 71 L.R.R.M. 2026 (Mich. Cir. Ct. 1969).

37 Id. at 2028.

38 Sloan v. Warrén Civil Serv. Comm'n, 76 L.R.R.M. 2479 (Mich. Ct. App. 1970); Nagy v. City of Detroit, 71 L.R.R.M. 2362 (Mich. Cir. Ct. 1969).

39 Sloan v. Warren Civil Serv. Comm'n, 76 L.R.R.M. 2479, 2481-82 (Mich. Ct. App. 1970), citing Mich. CoNST. art. XI, § 6.

40 "To permit the Common Council by simple ordinance to summarily sweep aside a merit system established by constitutional authority and by a vote of the electorate would be a mockery of our democratic process which in this day is already battered and bruised with too much abuse." Nagy v. City of Detroit, 71 L.R.R.M. 2362, 2369 (Mich. Cir. Ct. 1969). 
state has constitutional provisions for home rule. In these jurisdictions, the court's inquiry would only begin, not end, with the determination that a state statute conflicted with a local ordinance. The court would also have to determine whether the state statute was intended to preempt the field and whether the interests involved were statewide or local in nature. As past experience in constitutional home rule states has shown, these determinations are anything but automatic. ${ }^{41}$

Finally, the entire general supremacy theory collapses in those states in which either local civil service commissions are authorized by state statute or civil service itself is operated by a state commission. Under the general supremacy theory, courts in these states would be confronted with the Orwellian task of determining whether one state statute was more equal than another state statute.

A second general theory of reconciling statutes that has been employed in the civil service-collective bargaining context involves the argument that specific statutes override more general legislation. Thus, one Michigan court ${ }^{42}$ ruled that collective bargaining took precedence over civil service because the Michigan Public Employment Relations Act was specific while the local civil service regulations were general. Employees, therefore, could choose whether they were to be governed by collective bargaining agreements or by civil service regulations. ${ }^{43}$ The major defect in this approach is that, like the general supremacy theory, it is difficult to apply. Whether a particular statute is "general" or "specific" and whether it is "more specific" than another piece of legislation are complex and rather unrealistic questions. Indeed, prior to the decision noted above, the Michigan Attorney General had ruled that the public bargaining statute was general, and that it did not take precedence over specific statutes allowing school administrators to set fringe benefits for teachers unilaterally. ${ }^{44}$

Similar criticism can be leveled against a third method of statutory reconciliation-the subsequent enactment doctrine. The Wisconsin

41 See, e.g., the problems California courts have had in determining whether state statutes overruled local ordinances. In re Lane, 58 Cal. 2d 99, 372 P.2d 897, 22 Cal. Rptr. 857 (1962) (concurring opinion) (court must determine conflict between local ordinance and state statutory scheme by examining statute and facts and circumstances under which the statute operates); In re Hubbard, 62 Cal. 2d 119, 396 P.2d 809, 41 Cal. Rptr. 393 (1964) (chartered counties and cities can legislate in regard to municipal affairs unless state legislature has preempted field or expressed desire to preempt, or if transient citizens will be harmed); Bishop v. City of San Jose, 1 Cal. 3d 56, 460 P.2d 137, 81 Cal. Rptr. 465 (1969) (overruling Hubbard, stating that legislature's desire to deal with subject on statewide basis is not conclusive).

42 City of Warren v. Firefighters Local 1383, 68 L.R.R.M. 2977 (Mich. Cir. Ct. 1968).

$43 \mathrm{Id}$. at 2978.

44 Mich. ATr'y Gen. Op. No. 4583 (1968), discussed in Rayburn v. Board of Educ., 71 L.R.R.M. 2177, 2178 (Mich. Cir. Ct. 1969). 
Employment Relations Commission (WERG) and Wisconsin courts have resolved some conflicts between collective bargaining and traditional employer-civil service prerogatives by viewing Wisconsin's public bargaining statute as a subsequent enactment which has modified or limited earlier statutory provisions. Under this approach, the public employment statute's prohibition of discharge for union activity has been interpreted as limiting the statutory power of employers to discharge their employees; ${ }^{45}$ and fire and police chiefs, formerly given complete control over the working conditions of their men by state statute and city charter, have been required to bargain over wages, hours, and working conditions. ${ }^{46}$ The subsequent enactment approach assumes legislative awareness of existing statutes and, in the event of unreconcilable conflict, infers that later statutes were intended to limit previously adopted legislation. ${ }^{47}$ Such a presumption, however, is particularly suspect on the state level, since few states publish legislative hearings, committee reports, or floor debates. Thus, while the subsequent enactment doctrine may provide a simple means for reconciling the collective bargaining-civil service conflict, it fails to consider the important policy issues raised by these competing approaches.

Eschewing these more general approaches to statutory resolution, some courts in Michigan and the WERG have employed methods of analysis tailored more specifically to the collective bargaining-civil service conflict. Two lines of cases have relied heavily on specific statutory language to compensate for the dearth of materials recording legislative intent. The first concentrates on the words "wages, hours, and other terms and conditions of employment" 48 which define the bargaining duty in most public bargaining statutes. Emphasizing that this language is used also in the National Labor Relations $\mathrm{Act}^{49}$ and in many state employment peace acts, ${ }^{50}$ these courts assume that legislators using such language in public bargaining statutes were aware of the meaning attributed to it in the private sector. Because the public employee bargaining statutes usually contain no provisions limiting the bargaining obligation (as is noted below, ${ }^{51}$ some statutes require

45 Muskego-Norway Consol. Schools Joint School Dist. 9 v. Wisconsin Employment Relations Bd., 35 Wis. 2d 540, 557, 151 N.W.2d 617, 625 (1967).

46 Professional Policemen's Protective Ass'n v. City of Milwaukee, WERC Dec. No. 9429 (1970); Ruditys v. Gity of Milwaukee, WERC Dec. No. 8420 (1968).

47 Moberly, Developments in Municipal Labor Law, 42 Wis. BAR BuLl. 16, 17 (1969).

48 See, e.g., Conn. Stat. ANN. \& 7-469 (Supp. 1970) (duty to bargain "with respect to wages, hours, and other conditions of employment").

4929 U.S.C. $\S 158$ (d) (1964) ("wages, hours, and other terms and conditions of employment").

50 See, e.g., Mrch. Srat. ANN. § 17.454(32) (1968).

51 See text and notes at notes 85-87 infra. 
bargaining over "wages, hours, and terms and conditions of employment" but then exclude civil service matters from this bargaining duty), the statutory language has been broadly interpreted to include any aspect of employment that "has any reasonable relation to"52 or which "directly and intimately affects" 53 wages, hours, and working conditions. Under this approach, the courts and the WERC rely upon decisions from the private sector and upon their own interpretations of the bargaining duty in requiring bargaining over many matters traditionally under civil service regulation, such as job classification, ${ }^{54}$ union security, ${ }^{55}$ and department reorganization ${ }^{56}$ (which involves reclassification, determination of new job duties, and elimination of jobs). And employees have been allowed to bargain in these areas even where previously enacted statutes specifically foreclosed them from bargaining. ${ }^{57}$

The reliance of this approach on private sector case law is questionable, however, and may not be well suited to the resolution of the collective bargaining-civil service conflict. The analogy between the public and private sector is tenuous at best. Since public employers lack the same profit motive as private employers, they might forego hard bargaining in favor of a mutually acceptable accommodation with public unions. No guarantee exists that such an accommodation would not completely eliminate civil service and reinstate, to some extent, the spoils system. It is at least doubtful whether state legislators, in using the words "wages, hours, and terms and conditions of employment," meant to invite the complete destruction of civil service.

A second line of cases relying on statutory construction examines the language of city charters which outline the powers of city governing commissions over the working conditions of their employees. In a case in which the city charter granted the city commission "the legislative and administrative powers of the city," and in which prior court deci-

52 Rayburn v. Board of Educ., 71 L.R.R.M. 2177, 2179 (Mich. Cir. Ct. 1969).

53 Local 594, Milwaukee Dist. Council 48, AFSCME Petition to Initiate Fact Finding, WERC Dec. No. 9904 (1970), BNA Gov't EMpl. Rel. Rep. No. 368, Sept. 28, 1970, at B-1, enforced, WWERC Dec. No. 9904-B, BNA Gov'T EMPL. REL. REp. No. 387, Feb. 8, 1971, at B-9.

54 Local 594, Milwaukee Dist. Council 48, AFSCME Petition to Initiate Fact Finding, WERC Dec. No. 9754 (1969); Local 594, Milwaukee Dist. Council 48, AFSCME Petition to Initiate Fact Finding, WERC Dec. No. 8137-B (1967).

55 Nagy v. City of Detroit, 71 L.R.R.M. 2362 (Mich. Cir. Ct. 1969); Clampitt v. Board of Educ., 68 L.R.R.M. 2996 (Mich. Cir. Ct. 1968).

56 Local 594, Milwaukee Dist. Council 48, AFSCME Petition to Initiate Fact Finding, WERC Dec. No. 9904 (1970), BNA Gov'T EMPL. REL. REP. No. 368, Sept. 28, 1970, at B-1, enforced, WERC Dec. No. 9904-B, BNA Gov't EMPL. REL. REP. No. 387, Feb. 8, 1971, at B-9.

57 See cases cited notes 46 \& 52 supra. 
sions had upheld the right of the city commission to dismiss employees on good faith grounds, the court allowed the city to enter into a bargaining agreement requiring payment of the equivalent of union dues as a condition of employment and dismissal of employees who failed to meet this condition..$^{58}$ The civil service board was limited to a procedural adjudicatory function. It could only examine whether the employee had in fact failed to pay union assessments; it could not determine whether failure to pay was a valid ground for discharge. ${ }^{59}$ Such an interpretation allows the public employer to enter into collective bargaining agreements which infringe upon the substantive rulemaking power of civil service, provided he submits to its procedural adjudicatory power.

Thus, although the two statutory language approaches relate specifically to the problems of the collective bargaining-civil service conflict, they, like the more general methods of reconciliation discussed previously, attempt to resolve the conflict on an all-or-nothing basis. The inquiry centers on whether, on an abstract level, the collective bargaining statute is superior or inferior to the civil service authorization. To avoid this problem, some courts and the WERC have adopted an entirely different approach. Rather than establishing an all-encompassing hierarchy, this approach considers the public policy reasons behind both civil service and public employment bargaining statutes and attempts to evaluate individual contract terms in light of those policies.

Under this approach, a number of collective bargaining agreements have been upheld even though contrary to civil service regulations. Agency shop clauses, for example, have been validated on two grounds. In some cases they were found compatible with the goals of civil service-retaining competent employees and insulating them from arbitrary political and personal interference, ${ }^{60}$ and in another case the court ruled that "the more logical rationale behind the agency shop outweighs the more emotional arguments of its opponents."61 The logical rationale to which the court referred stipulated that members of a

58 Gity of Grand Rapids v. Local 1061, AFSCME, 72 L.R.R.M. 2257 (Mich. Cir. Ct. 1969). This general contract-making power was recognized in Smigel v. Southgate Community School Dist., 74 L.R.R.M. 3080 (Mich. Ct. App. 1970), where an agreement called for a Teacher Tenure Commission (the equivalent of civil service for teachers) hearing for teachers accused of not paying agency fees required by the same contract.

59 The court compared the requirement of agency fees to mandatory contributions to a pension fund: the employer could require employees to contribute to both. The court illustrated the procedural role of civil service by noting that if an employer sought to discharge an employee for constant tardiness, civil service could determine only whether in fact the employee had been tardy; it could not decide whether 8:30 rather than 8 a.m. is a reasonable starting time.

60 Clampitt v. Board of Educ., 68 L.R.R.M. 2997, 2999 (Mich. Cir. Ct. 1968).

61 Nagy v. City of Detroit, 71 L.R.R.M. 2362, 2363 (Mich. Cir. Ct. 1969). 
bargaining unit should pay for their representation by the union and that failure to observe a union security provision could well "undermine the whole principle of fair collective bargaining," 62 since strong unions were needed to stand up to employers and to make negotiations productive. No empirical data were cited to support this rationale.

Similarly, public policy has been invoked as the basis for the extension of collective bargaining to both fringe benefits ${ }^{63}$ and department reorganizations. ${ }^{64}$ The court which allowed fringe benefit agreements relied on a legislative purpose to give public employees "many of the rights and kinds of contractual benefits gained by workers in private employment by the collective bargaining process, except as the same would be repugnant to existing laws or an abuse of the authority of the public employer ...." 65 The department reorganization rested on the possibility that union suggestions would contribute to government efficiency:

If the petitioner is given an opportunity to bargain with respect to the decision to reorganize the department of public welfare, as well as its effect on the work of bargaining unit employees, it can attempt to persuade the municipal employer that the proposed reorganization might not be as efficient as contemplated. It would be able to propose suggestions and comments as to how the reorganization might better be implemented to achieve the goals desired by the municipal employer. ${ }^{66}$

Public policy considerations have not, however, operated consistently to expand the scope of collective bargaining. One court, for example, refused to allow the employer and union to exclude the civil service commission from bargaining sessions, relying on the need to prevent the return of the spoils system. ${ }^{67}$

It is difficult to deny the inherent advantages of a policy-oriented

62 Id. at 2364 .

63 Rayburn v. Board of Educ., 71 L.R.R.M. 2177, 2178 (Mich. Cir. Ct. 1969).

64 Local 594, Milwaukee Dist. Council 48, AFSCME Petition to Initiate Fact Finding, WERC Dec. No. 9904 (1970), BNA Gov'r EMPL. REL. REP. No. 368, Sept. 28, 1970, at B-1, B-2, enforced, WERC Dec. No. 9904-B, BNA Gov'T EMPL. REL. REP. No. 387, Feb. 8, 1971, at B-9.

6571 L.R.R.M. at 2178. Instead of relying upon legislative hearings, reports, or debates, the court turned to an article concerning the Michigan Public Employment Relations Act, written by Robert G. Howlett, Chairman of the Michigan Labor Relations Board.

66 Local 594, Milwaukee Dist. Council 48, AFSCME, Petition to Initiate Fact Finding, WERC Dec. No. 9904 (1970), BNA Gov'r Empl. ReL. REP. No. 368, Sept. 28, 1970, at B-1, B-2. It should be noted that this broad language could justify bargaining on almost any civil service topic.

67 Nagy v. City of Detroit, 71 L.R.R.M. 2362, 2366-69 (Mich. Cir. Ct. 1969). 
analysis. Only an academic heretic would prefer either a mechanical legal standard or a test based on bare statutory language to a reasoned decision reflecting underlying policies. Yet it would be wrong to minimize the difficulties which arise from this approach. The court must consider a number of issues which may touch upon the legislative domain $^{68}$ and, as previously mentioned, ${ }^{69}$ it will usually have to do so without much assistance from legislative hearings, committee reports, or floor debates. The attendant difficulties may readily be perceived. To determine the scope of public collective bargaining, for example, the court must evaluate the effect of public employee strikes. It may be desirable to give public employees greater control over their working conditions because theoretically they cannot strike to obtain higher pay from cost-conscious officials. ${ }^{70}$ One may also seek alternate ways of settling disputes-among them, arbitration of grievances-so that strong public employee unions will not feel forced to strike illegally to gain satisfactory resolution of such disputes. ${ }^{71}$ Conversely, the tendency of public employees to engage in strikes, legal or illegal, over bargainable issues may militate against expansion of bargaining into civil service matters. The legislature may not have wanted some matters, such as examinations, hiring practices, and promotions, to be determined by strikes and other displays of force. It may be better to exclude such matters from bargaining altogether.

A more basic policy decision which a court must make in determining the scope of bargaining concerns the goals to be served by civil service. If one views civil service merely in terms of its original function of eliminating the spoils system, ${ }^{72}$ then the role of collective bargaining

68 Employment relations boards, in their role as adjudicatory and policy-making agencies, may be better suited than courts to consider such issues. It has been argued that the difficulty and complexity of some types of policy determinations require that the legislative body provide specialized administrative tribunals to develop policy on a case-by-case basis. 1 K.C. Davis, Administrative LAw Treatise § 2.05, at 98-99 (1958). Perhaps these boards present the best possibility for resolving the collective bargainingcivil service conflict.

69 See text following note 47 supra.

70 See authorities cited note 17 supra.

71 Courts have used this rationale to justify a broad construction of grievance arbitration provisions. Greenfield Educational Ass'n v. Joint School Dist. 6, BNA Gov'T EMPL. REL. REP. No. 360, Aug. 3, 1970, at B-2 (Wis. Cir. Ct. 1970); City of Madison v. Wisconsin Employment Relations Bd., 65 L.R.R.M. 2488, 2491 (Wis. Cir. Ct. 1967).

72 See authorities cited note 8 supra. See also Mosher, supra note 9, at 65:

[A]lthough some protagonists mentioned efficiency as an argument for a merit system, this was at best a secondary consideration-"and not a very close second at that," to quote Paul P. Van Riper's analysis of the movement. [The civil service reform movement] was essentially a negative movement designed to stamp out a system which was a "disgrace to republican institutions"- to eradicate evil. There was not very much original thought about the best kind of substitute for spoils beyond competitive entrance examinations and security of tenure. 
should be greatly expanded. The important function performed by the civil service system under this view is the elimination of unwarranted employer discretion and the enforcement of non-arbitrary standards, rather than the determination of the actual content of the standards. Collective bargaining could be given final authority to establish fixed rules governing hiring, promotion, transfer, discharge, and employment conditions without presaging a return to the spoils system. ${ }^{73}$ The necessary task of identifying clear and intelligible standards for controlling executive discretion can be accomplished as effectively by the collective bargaining process as by a civil service commission. ${ }^{74}$ Though a merit evaluation program devised unilaterally by civil service may produce more efficient employees than would a seniority system produced by negotiation, ${ }^{75}$ the latter method certainly prevents arbitrariness through application of objective and uniform criteria. Similarly, whatever one may think about the ability of private arbitrators, ${ }^{76}$ they do not seem more biased toward either union or employer than are civil service commissions ${ }^{77}$ Although union security agreements place an extra condition on public employment-that is, the payment of dues-they do not subject employees to arbitrary discrimination. ${ }^{78}$

The decision for a court becomes more difficult if purposes other than the elimination of the spoils system are attributed to civil service. Thus, if efficiency of governmental operations is seen as an important goal, much of the previous argument collapses. The content of objective

73 "Apart from the employment of new applicants, the 'merit principle' probably should be pursued through collective bargaining and not through a civil service system." Wellington \& Winter, Structuring Collective Bargaining in Public Employment, 79 YALE L.J. 805,864 (1970).

74 Some commentators have observed and documented the arbitrariness of certain civil service commissions. U.S. CoMm'N on HuMAN RIGHTs, supra note 2, at 65-68. See also LEAGUE OF WOMEN VOTERS OF MASSAChUSETTS, supra note 8, at 34:

The procedure followed by many public personnel agencies in determining the relative weights to be assigned to experience and education, as well as other parts of the test battery, is simply the guess of the examiner as to the importance of each.

Unions could provide the "aggressive, militant approach" toward determining the validity and importance of civil service testing processes and improving the techniques of examinations which has been sorely lacking. Kaplan, supra note 11, at 221.

75 Nigro, The Implications for Public Administration, 28 PuB. Ad. REv. 137, 144 (1968).

76 P. Hays, Labor Arbitration: A Dissenting View 49, 59, 61-70, 112 (1966).

77 See text at note 5, supra. Commentators have suggested the introduction of arbitration into public employment to encourage reasonableness in the earlier stages of grievance resolution and to uplift employee morale. Killingsworth, Grievance Adjudication in Public Employment, 13 ARB. J. 3, 15 (1958). Killingsworth suggests that civil service commissions are inherently incapable of impartiality because of their dual functions of representing the public interest in protecting public servants and of performing managerial tasks. Id. at 11-12.

78 See discussion of this point in City of Grand Rapids v. Local 1061, AFSCME, 72 L.R.R.M. 2257, 2262 (Mich. Cir. Ct. 1969). 
standards governing hiring, promotions, transfers, and grievances cannot be left to the employer and union because the public employer, unlike his counterpart in the private sector, lacks the profit incentive to engage in hard bargaining to maximize efficiency.

Similarly, the use of civil service to achieve social goals, such as transferring teachers into inner-city schools or advancing minority group employment, may be antithetical to expansion of collective bargaining. The sheer number of bargaining units negotiating independently of one another may make any uniform policy impractical to administer. ${ }^{70}$ Moreover, even disregarding these unit determination problems, the mutual interests of employers and employees may prove quite different from the social policies sought to be advanced. ${ }^{80}$ Expansion of collective bargaining, therefore, might increase the impediments to achieving those goals.

These difficulties are not insurmountable, however, and civil service is not the only means of solving them. For example, minority groups may be aided by public sector equivalents of the Philadelphia Plan, ${ }^{81}$ civil rights laws, and equal opportunity regulations. Conceivably, judicial review could be used to secure the fulfillment of vital government objectives. A New Jersey court ${ }^{82}$ recently invalidated a collective bargaining clause which impeded the promotion of black teachers in innercity schools. Yet it is questionable how far a court should go, as a matter of policy, in requiring that social objectives presently achieved through civil service be pursued via alternate means.

The above problems should not be taken as a mandate either for judicial inaction ${ }^{83}$ or for adoption of one of the mechanical tests previ-

79 N.Y. GOVERNOR's CoMm. ON PUblic EMPLOyeE RELATIONS, FINAL REPORT 10-12 (1966).

80 Stanley has observed resistance on the part of public employee unions to the granting of preferred positions to less privileged workers for selection and training purposes. Stanley, supra note 3 , at 110 .

81 For a description of the plan, see Contractors Ass'n v. Shultz, 62 CCH LAB. CAs. If 9421 (E.D. Pa. 1970). The court upheld the plan against charges that it violated the 1964 Civil Rights Act.

82 Porcelli v. Titus, 108 N.J. Super. Ct. 301, 261 A.2d 364 (1969). The collective bargaining agreement between the school board and the teachers' union called for promotions on merit alone, but the court applied a "changed circumstances" contract theory to declare the bargaining agreement void.

83 Courts may do much to increase bargainable topics without disturbing valid civil service regulations. For example, courts can allow bargaining to define the meaning of certain civil service regulations. In Zekas v. Baldwin, 310 F. Supp. 575 (E.D. Wis. 1970), a court granted a temporary restraining order against dismissal of a welfare worker because the regulations under which he was dismissed were overly broad. There should be no opposition to bargaining for the purpose of clarification when the alternative is unconstitutionality. Similarly, collective bargaining could provide for penalties for the violation of civil service laws when the laws themselves are silent. In Miami v. Gioia, 69 L.R.R.M. 2735 (Fla. Dist. Ct. App. 1968), the court held that an employer had violated civil service regulations by working firemen more than thirty days in a higher classification, but determined that no extra pay would be given the firemen because no regulation so 
ously described. Although the legislature may have failed to provide any clear indication of its intent in enacting the public employee bargaining statute, the judicial function requires that the court, when the issues are properly presented, decide conflicts between the respective spheres of civil service and collective bargaining. Of course, it is preferable that the court's decision rest upon sound considerations of policy rather than upon the artificial characterization of a statute as "general" or "specific." But the policy questions which must be resolved are varied and complex, and the judicial forum may not be the most appropriate one in which to resolve the decision. Both the nature of the questions and the difficulty of answering them present a strong case for legislative intervention.

\section{Existing and Alternative Legislative Resolutions OF THE CONFLICT}

\section{A. Existing Legislative Resolutions}

In a number of states, legislatures have attempted to reconcile the competing power claims of civil service and public employee collective bargaining. Five different approaches have been adopted. First, six states $^{8 *}$ have resolved the collective bargaining-civil service conflict by excluding all civil service matters from collective agreements. Through statutory language subjecting collective bargaining settlements to civil service regulations, ${ }^{85}$ excluding civil service matters from negotiation, ${ }^{86}$

required. Bargaining should fill such gaps. Finally, courts should scrutinize the statutory grants of power to civil service and allow bargaining to govern categories outside these grants. Courts have limited the rule-making power of civil service commissions in the past, and can do so in the future to open new areas for bargaining. Essling v. St. Louis County Givil Serv. Comm'n, 283 Minn. 425, 168 N.W.2d 663 (1969) (civil service commission could not set mandatory retirement age when statute establishing commission did not include such authority); State ex rel. Baranowski v. Koszewski, 251 Wis. 383, 29 N.W.2d 764 (1947) (civil service commission could not both bring charges against employee and then adjudicate them, for legislature had not given commission such power).

84 See note 19 supra.

85 R.I. GEN. LAWS ANN. § 36-11-5 (Supp. 1970):

Whenever the procedures under a merit system statute or rule are exclusive with respect to matters otherwise comprehended by this chapter, they shall apply and be followed.

VT. STAr. ANN. tit. 3, § 904(b):

This chapter shall not be construed to be in derogation of, or contravene the spirit and intent of the merit system principles and the personnel laws.

§ 905 provides:

The governor, or a person designated by him, . . . shall act as the employer representative in collective bargaining negotiations and administration. The representative shall be responsible for insuring consistency in the terms and conditions in various agreements throughout the state service, insuring compatibility with merit system statutes and principles, and shall not agree to any terms or conditions for which there are not adequate funds available.

86 Hawaii Public Employee Collective Bargaining Act, \& 9(d), No. 171, [1970] Hawaii Acts 816: 
or forbidding any diminution of the power of civil service commissions, ${ }^{87}$ this legislation effectively preserves the authority of civil service. These laws assume that civil service regulations are generally preferable to negotiated agreements. As a result, such regulations are granted legislative protection without regard to their desirability. Moreover, employers in these states can eliminate bargainable issues simply by having the civil service commission expand the scope of its regulations.

In some situations, it might be to the union's advantage to bargain to increase the power of civil service. ${ }^{88}$ It is quite possible in these six states for agreements between unions and public employers to designate civil service and personnel boards as higher appeal agencies in localities where unions fear arbitrariness in discharge actions and have sufficient trust in civil service.

Second, in those states ${ }^{89}$ in which legislatures have not authorized public employers to bargain with their employees, the conflict seems

Excluded from the subjects of negotiations are matters of classification and reclassification, retirement benefits and the salary ranges and the number of incremental and longevity steps now provided by law .... The employer and the exclusive representative shall not agree to any proposal which would be inconsistent with merit principles or the principle of equal pay for equal work ... or which would interfere with the rights of a public employer to (1) direct employees; (2) determine qualifications, standards for work, the nature and contents of examinations, hire, promote, transfer, assign, and retain employees in positions, and suspend, demote, discharge, or take other disciplinary actions against employees for proper cause; (3) relieve an employee from duties because of lack of work or other legitimate reason; (4) maintain efficiency of government operations; (5) determine methods, means, and personnel by which the employer's operations are to be conducted; and take such actions as may be necessary to carry out the missions of the employer in cases of emergencies.

N.J. REv. STAT. § 34.13A-5.3 (Supp. 1970):

Nothing herein shall be construed to deny to any individual employee his rights under Civil Service Laws or regulations.

The New Jersey Supreme Court has apparently interpreted this provision and the entire bargaining law to exclude any changes in civil service regulations. Lullo v. Firefighters Local 1066, 55 N.J. 409, 440, 262 A.2d 68I, 697 (1970).

PA. STAT. tit. 43, \& 1101.703 (Supp. 1971):

The parties to the collective bargaining process shall not effect or implement a provision in a collective bargaining agreement if the implementation of that provision would be in violation of, or inconsistent with, or in conflict with any statute or statutes enacted by the General Assembly of the Commonwealth of Pennsylvania or the provisions of municipal home rule charters.

87 MASS. GEN. LAwS ch. 149, \& 178N (Supp. 1970):

Nothing in sections [178F-178M, which authorize municipal employees to bargain] shall diminish the authority and power of the civil service commission. . . .

N.H. REv. STAT. ANN. ch. 98-G:7 (Supp. 1970) guarantees the exclusive right of the state to appoint, promote, discharge, transfer, or demote employees; to direct and supervise; to lay off unnecessary employees; and to maintain the efficiency of government operations. Ch. 98-C:4(b), however, allows negotiation to establish procedures and steps for conferring upon and considering recommendations for improvement in personnel policies and changes in classifications and allocations.

88 Local 572, AFSCME v. City of Dover, 109 N.H. 299, 301, 249 A.2d 681, 683 (1969).

89 See note 18 supra. 
to have been resolved as if there had been an explicit legislative pronouncement forbidding collective bargaining from displacing civil service regulations. The state courts have reached this result on the grounds ( 1 ) that control over working conditions is a discretionary power that cannot be delegated, or (2) that the proposed agreements are incompatible with statutorily authorized civil service goals. The first approach, which is premised on the belief that employment conditions -qualifications, classification, tenure, working rules-should be determined solely by legislative fiat, ${ }^{90}$ has both broad and narrow applications. Under the broad reading, parties may not bargain on any matter relating to employment, even in those areas where a civil service commission has not passed any regulations. ${ }^{91}$ The narrow reading allows parties to bargain over employment matters, ${ }^{92}$ but only if the civil service commission has not yet adopted regulations to cover such matters. ${ }^{93}$ Of course, if the civil service commission later enacts regulations that conflict with previously bargained-for agreements, inconsistent clauses of the bargaining contract are invalidated.94 The second approach evaluates the effect of contract terms upon the civil service

90 Fort Smith v. Council 38, AFSCME, 245 Ark. 409, 433 S.W.2d 153 (1968); City of Los Angeles v. Los Angeles Bldg. \& Constr. Trades Council, 94 Cal. App. 2d 36, 210 P.2d 305 (1949) (superseded in California by passage of a public employee bargaining act); Fellows v. La Tronica, 151 Colo. 300, 377 P.2d 547 (1962); Wichita Pub. Schools Employees Local 513 v. Smith, 194 Kan. 2, 397 P.2d 357 (1964); Hagerman v. City of Dayton, 147 Ohio St. 313, 71 N.E.2d 246 (1947). See also Anderson, Labor Relations in the Public Service, 1961 Wis. L. REv. 601, 618-19.

91 "Labor unions have no function which they may discharge in connection with civil service appointees." Hagerman v. City of Dayton, 147 Ohio St. 313, 328-29, 71 N.E.2d 246, 254 (1947). In Foltz v. City of Dayton, 75 L.R.R.M. 2321 (Ohio Ct. App. 1970), the court upheld the invalidation of a union security clause in a bargaining contract, relying on Hagerman. The two concurring judges expressed their hope that the Ohio Supreme Court would overrule Hagerman, believing that collective bargaining was the most satisfactory way of handling a government's relations with its employees. Hagerman has been cited numerous times in other states which have denied bargaining rights to public employees.

92 Local 61l, IBEW v. Town of Farmington, 75 N.M. 393, 405 P.2d 233 (1965); Local 266, IBEW v. Salt River Project, Agr. Impr. \& Power Dist., 78 Ariz. 30, 275 P.2d 393 (1954).

93 This narrower theory is more plausible than the broader one which forbids any delegation of power. It is easy to see under the narrow theory why parties should not be allowed to circumvent by collective agreement civil service regulations already on the books-allowing people to agree to ignore laws would hardly be consistent with orderly government. But the broader theory forbidding parties to agree on matters not yet covered by civil service regulations is questionable. The nondelegation rule has been attacked on the grounds that it overstates the reasons for prohibiting delegations of legislative authority (see State v. City of Laramie, 437 P.2d 295, 300 (Wyo. 1968)), and that collective bargaining poses no compulsion to sign an agreement and does not deprive the employer of final decision (see State Board of Regents v. Packinghouse, Food \&: Allied Workers Local 1258, - Iowa -, 175 N.W.2d 110, 113 (1970)).

94 Local 611, IBEW v. Town of Farmington, 75 N.M. 393, 397, 405 P.2d 233, 236 (1965). 
system. Although this analysis would seem to allow courts to uphold collective bargaining agreements having only minor adverse effects on civil service, the courts have consistently used this approach to uphold the power of the civil service commissions. For example, the courts have voided union security agreements on the ground that dismissal of employees for failure to pay union dues is incompatible with civil service's retention of employees on merit. ${ }^{95}$ Similarly, arbitration by an outside party has been prohibited because an arbitrator would be unacquainted with the civil service laws he was supposed to enforce. ${ }^{96}$ Thus, in the absence of an express authorization of public employee bargaining, the courts tend to subordinate the policy considerations to a questionable legislative intent to have employment and tenure depend solely on merit as measured by civil service regulations.

A third type of legislative reconciliation, adopted in four states, ${ }^{97}$ imposes a duty to bargain collectively or to "meet and confer" upon public employers and unions, but exempts civil service matters from this duty. These statutes generally retain certain public employer prerogatives through a management rights section, but do not prohibit agreements affecting civil service regulations. ${ }^{98} \mathrm{~A}$ public employer is

95 Petrucci v. Hogan, 5 Misc. 2d 480, 27 N.Y.S.2d 718 (Sup. Ct. 1941); Civil Serv. Comm'n v. Ballard, BNA Gov'T EMPL. REL. REP. No. 344, Apr. 13, 1970, at B-1 (Ohio C.P. 1970). An alternative holding in Ballard was that the agency shop clause was invalid because it violated the equal protection clause-nonunion employees would be treated differently under the bargaining contract than without it because they would have to pay agency fees.

96 City of Cleveland v. Street, Elec. Ry. \& Motor Coach Employees Div. 268 (Ohio G.P. 1945), reported in C. RHYNe, LABor Unions AND MUNicipal EMPloyer LAw (1946).

97 See note 21 supra.

98 CAL. Gov'T CODE $\$ 3500$ (Supp. 1971):

Nothing contained herein shall be deemed to supersede the provisions of existing state law and the charters, ordinances, and rules of local public agencies which establish and regulate a merit or civil service system or which provide for other methods of administering employer-employee relations. This chapter is intended, instead, to strengthen merit, civil service and other methods of administering employer-employee relations through the establishment of uniform and orderly methods of communication between employees and the public agencies by which they are employed.

\section{$\S 3504$ provides:}

The scope of representation shall include all matters relating to employment conditions and employer-employee relations, ... except, however, that the scope of representation shall not include consideration of the merits, necessity, or organization of any service or activity provided by law or executive order.

The failure of the prohibitory section to exclude civil service matters from the scope of representation can be interpreted as permitting negotiation over such matters, if the employer and union so wish. $\S 3500$ can then be read as merely removing civil service matters from the scope of mandatory bargaining.

NEv. REv. STAT. § 288.150(2) (Supp. 1970):

Each local government employer is entitled, without negotiation or reference to any agreement resulting from negotiation:

a. To direct his employees;

b. To hire, promote, classify, transfer, assign, retain, suspend, demote, discharge or take disciplinary action against any employee; 
apparently free to negotiate agreements contrary to civil service regulations. For example, in one case a union sought to enforce a strike settlement agreement by which a county employer consented to reinstate employees who had violated civil service regulations prohibiting unjustified absences from work.99 In holding that the union had stated a cause of action, the court said:

[T] he statute neither requires collective bargaining nor precisely defines the rights which flow to public employees and the nature and scope of the contract that can be entered into by the parties. The statute does, however, apparently envision that agreements reached as the result of such conferences and meetings are now compatible with civil service and merit systems. ${ }^{100}$

c. To relieve any employee from duty because of lack of work or for any other legitimate reason;

d. To maintain the efficiency of its governmental operations;

e. To determine the methods, means and personnel by which its operations are to be conducted; and

f. To take whatever actions may be necessary to carry out its responsibilities in situations of emergency.

WIs. STAT. § 111.91(2) (Supp. 1970):

Nothing herein shall require the employer to bargain in relation to statutory and home rule provided prerogatives of promotion, layoff, position classification, compensation and fringe benefits, examinations, discipline, merit salary determination policy and other actions provided for by law and rules governing civil service.

Wash. REv. CoDE § 41.56 .100 (Supp. 1971):

[N]othing contained herein shall require any public employer to bargain collectively with any bargaining representative concerning any matter which by ordinance, resolution or charter of said public employer has been delegated to any civil service commission or personnel board similar in scope, structure and authority to the board created by chapter 41.06 RCW.

\$ 41.56.130 of the Washington public employee bargaining statute incorporates $\$ 41.06 .150$ of the personnel laws. The latter statute provides that the personnel board shall establish the basis and procedures for dismissal, suspension, demotion, appeals from disciplinary action, certification for filling vacancies, examinations, appointments, probationary periods, transfers, sick leave, hours, and layoffs. It stipulates further:

Provided, That in making such determination the board shall consider the duties, skills, and working conditions of the employees, the history of collective bargaining by the employees and their bargaining representatives, the extent of organization among the employees, and the desires of the employees; certification and decertification of exclusive bargaining representatives; agreements between agencies and certified exclusive bargaining representatives providing for grievance procedures and collective negotiations on all personnel matters over which the appointing authority of the appropriate bargaining unit of such agency may Iawfully exercise discretion .....

It is conceivable that employer voluntary agreements to change civil service regulations may still run afoul of the problems discussed in the text at notes 38-41 supra.

99 East Bay Municipal Employees Local 390 v. County of Alameda, 3 Cal App. 3d 578, 83 Cal. Rptr. 503 (1970). Civil service regulations required that employees absent without excuse be terminated immediately with full loss of seniority benefits. In addition, terminated employees could be reinstated without prejudice only if they presented a reasonable excuse within three days after their absence.

$100 \mathrm{Id}$. at 584, $83 \mathrm{Cal}$. Rptr. at 507 (emphasis in original). Other courts have refused to enforce strike settlement agreements granting nondiscriminatory reinstatement or increased remuneration to returning strikers. See, e.g., Almond v. County of Sacramento, 
The court concluded that when a public employer engages in bargaining with public employees, any agreement that the public agency is authorized to make and does make should be valid and binding on all parties-union, employer, and civil service commission.

This case illustrates a major disadvantage of such "permissive" legislation. The union used an illegal strike to convince the employer to participate "voluntarily" in meaningful negotiations. Other unions may resort to similar displays of power if they perceive that the employer can be forced to negotiate civil service provisions, deemed important to their members. As a result, the negotiability of civil service regulations is determined by shows of force rather than by rational decisions as to the desirability of isolating these rules from negotiation.

A fourth legislative approach, adopted by Connecticut and Maine, ${ }^{101}$ allows collective bargaining agreements to supersede civil service regulations, but forbids negotiation relating to rules for the conduct and grading of examinations, candidate rating, and promotions from rating lists. These statutes recognize that civil service rules should not present a monolithic barrier to all bargaining and reflect a legislative judgment as to which aspects of civil service should be immune from bargaining. ${ }^{102}$

276 Cal. App. 2d 32, 80 Cal. Rptr. 518 (1969); Head v. Special School Dist. No. 1, - Minn.

-, 182 N.W.2d 887 (1970); Goldberg v. City of Cincinnati, 23 Ohio App. 2d 97 (1970). 101 ConN. Gen. Stat. ANn. § 7-474(f) (Supp. 1970):

Where there is a conflict between any agreement reached by a municipal employer and an employee organization and approved in accordance with the provisions [of this act] and any charter, special act, ordinance, rules or regulations adopted by the municipal employer or its agents such as a personnel board or civil service system, . . . the terms of such agreement shall prevail.

$\S 7-474(\mathrm{~g})$ provides:

Nothing herein shall diminish the authority and power of any municipal civil service commission, personnel board, personnel agency or its agents established by statute, charter or special act to conduct and grade merit examinations and to rate candidates in the order of their relative excellence from which appointments or promotions may be made to positions in the competitive division of the classified service of the municipal employer served by such civil service commission or personnel board. The conduct and grading of merit examinations, the rating of candidates and the establishment of lists from such examinations and the appointments from such lists and any provision of any municipal charter concerning political activity of municipal employees shall not be subject to collective bargaining.

The Maine statute is almost identical. ME. Stat. ANN. ch. 26, § 969 (Supp. 1970).

102 The report which provided the impetus for the Connecticut law noted:

We have also included in this section a provision to protect the authority of civil service or other similar commissions in the matter of merit system examinations from which appointment and promotion lists are drawn. These procedures are not to be subject to collective bargaining. However, in order to clarify any question that may arise if a provision of an agreement is in conflict with other rules or regulations in the municipality we are providing that the terms of the agreement shall prevail. We are not nullifying or repealing such rules and regulations, but, as a practical matter, it is not possible to have two separate rules in effect at the same time covering the same subject matter.

ConN. Interim Comm'N to Study Collective Bargaining by MUNicipalities, Report 17 (1965). 
Finally, in Delaware the legislature has adopted a blanket rule favoring collective bargaining. A 1967 law repealed the section of Delaware's collective bargaining statute stipulating that merit procedures and statutes were not to be affected by bargaining, and guaranteed public employees a role in the formulation of certain aspects of personnel policy. ${ }^{103}$

\section{B. Alternative Resolutions}

The federal resolution of the conflict between public collective bargaining and civil service is found in Executive Order 11491, issued on January 1, 1970 by President Nixon. ${ }^{104}$ This order specifies that federal officials and employees are governed by the regulations of the Federal Personnel Manual, ${ }^{105}$ and that the government retains certain exclusive management rights, including the rights to hire, promote, demote, and discharge. ${ }^{108}$ The Civil Service Commission has indicated that certain fundamental principles, such as competitive selection of appointees, grading of positions according to legislative standards, promotion, and job protection, would not be subject to bargaining. ${ }^{107}$ The federal approach, then, restricts bargaining ability significantly.

Another possible resolution is the mandating of minimum civil service standards by a higher authority, as was proposed in the Intergovernmental Personnel Bill introduced in 1967.108 The bill would have required localities seeking government funds to meet certain minimum merit standards promulgated by a presidentially appointed commission. The standards would have covered recruitment, selection, and advancement on the basis of relative ability, knowledge, and skills; provided equitable and adequate compensation; trained employees to assure high-quality performance; and assured fair treatment of applicants and employees in all aspects of employment. ${ }^{109}$ The application

103 The law recognizes that "the statute establishing the merit system of personnel administration for the employees of the state did not expressly define its relationship to the statute recognizing the right of public employees to organize" and provides that collective bargaining could establish rules for classification, uniform pay scales, competitive examinations, promotions, eligibility lists, rejections for unfitness, appointment of superior applicants, leaves, veterans preference, and residency preference. $\mathrm{Ch}$. $376, \S 5938$, [1967] Del. Laws 1297.

104 The predecessor of this order was Exec. Order No. 10988, 3 C.F.R. 521 (1962), issued by President Kennedy. The provisions of the Nixon order relating to civil service are quite similar to those of the Kennedy order.

105 Exec. Order No. 11491, § 12(a), 3 C.F.R. 191, 199 (1969 Comp.).

106 Id. at $\S$ I2(b), 3 C.F.R. 19I, 199-200 (1969 Comp.).

107 U.S. Civil Service Comm'n, Federal Personnel Manual ch. 711.

108 S. 699, 90th Cong., 1st Sess. (1967), introduced by Senator Muskie. The Johnson Administration introduced its own version, The Intergovernmental Manpower Bill, S. 1485, 90th Cong., 1st Sess. (1967).

109 Hearings, supra note 12, at 21. 
of these principles above the minimum standards set by the commission would be a proper subject for negotiation between unions and employers. ${ }^{110}$ The bill was not enacted into law, however, partially due to opposition from local officials who have insisted that federal control is unnecessary. ${ }^{111} \mathrm{~A}$ state mandating of standards may be more acceptable. ${ }^{112}$

A final alternative is illustrated by the proposed National Public Employee Relations Act, written by the American Federation of State, County, and Municipal Employees. ${ }^{113}$ This Act would allow parties to agree on contract provisions superseding all merit regulations, but would require submission of the entire contract to the appropriate legislative body for ratification. ${ }^{114}$

\section{CONCLUSION}

It is beyond the scope of this comment to evaluate each of the alternatives discussed above. However, one point continues to emerge from the commentary and cases in this area. The central problem has been the failure of legislatures to define the respective parameters of the civil service commission and the collective bargaining process. This abdication of responsibility has placed the courts in the position of having to decide issues which involve subtle policy judgments concerning the purpose and function of the civil service system. It is understandable, therefore, that courts have usually attempted to avoid the problem by applying the traditional, if formalistic, rules of judicial construction. Even those courts which have tried to grapple with the underlying policies have often succeeded only in adding to the confusion. If the situation is to be remedied, legislative direction is indispensable. The Maine and Connecticut approach ${ }^{115}$ is illustrative of the manner in which a statutory response can facilitate the purposeful

110 Hearings, supra note 12, at 193 (remark of Senator Muskie).

111 For a summary of the Senate hearings on the bill, see BNA Gov'T EMPL. REL. REP. No. 191, May 8, 1967, at B-2.

112 Opposition even to state control would arise from home rule advocates. Advisory COMM'N ON INTERGOVERNMENTAL RELATIONS, supra note 6, at 83-84.

113 H.R. 17383, 91st Cong., 2d Sess. (1970).

$114 \S 13$ of the proposed Act states:

This Act shall supersede all previous statutes concerning this subject matter and shall preempt all contrary local ordinances, executive orders, legislation, rules or regulations adopted by any State or any of its political subdivisions or agents such as a personnel board or civil service commission.

$\S 5$ (c) defines the duty to bargain as the duty

... to negotiate about matters which are or may be the subject of regulation promulgated by any employer's agency or other organ of a state or subdivision thereof or of a statute, ordinance, or other public law enacted by any state or subdivision thereof, and to submit any agreement reached on these matters to the appropriate legislature.

115 See text and notes at notes 101-02 supra. 
interaction between a civil service system and public employee unionism. Moreover, legislative action can carefully adjust the scope of allowable collective bargaining in accordance with the issue involved, and thereby avoid the mechanical tendency to treat all terms and conditions of employment alike. ${ }^{116}$ The important point, though, is that the legislatures should act to resolve the present conflict between civil service and collective bargaining; for in the absence of such legislative direction, employers, employees, civil service commissions, and the judiciary are set adrift on a sea of doubt, usually leaving the courts as the scene of the ensuing shipwreck.

116 It is anticipated that the Wisconsin legislature will amend its bargaining statutes for public employees this year to make illegal bargaining over recruitment, position classification, allocation of classifications to salary levels, examinations, and probationary periods. Other matters currently under civil service regulation would be subject to mandatory bargaining. Wis. Governor's Advisory CoMm. ON STATE EMPLOYMENT RELATIONS, Tentative REPORT 8 (1970). A public employee bargaining statute recently defeated in Illinois adopted essentially the same approach. Clark, Public Employee Labor Legislation: A Study of the Unsuccessful Attempt to Enact a Public Employee Bargaining Statute in Illinois, 20 LAB. L.J. 164, 168 (1969). 